формування духовних потреб школярів засобами комплексу мистецтв потребують більш детального розгляду в подальших наукових дослідженнях.

\title{
Література
}

1. Бережной Н. М. Человек и его потребности / Николай Михайлович Бережной; [под ред. В. Д. Диденко]. - Москва : Московский государственный университет сервиса, 2000. 210 с. 2. Духовность, художественное творчество, нравственность (материалы «круглого стола») // Вопросы философии. - 1996. - № 2. - С. 9-12. 3. Кабалевский Д. Б. Эстетическая культура и школа / Д. Б. Кабалевский // Советская педагогика. - 1970. - № 1. - С. 24-25. 4. Каган М. С. Роль и взаимодействие искусств в педагогическом процессе / М. С. Каган // Музыка в школе. - 1984. - № 4. - С. 28-32. 5. Маслоу А. Дальние пределы человеческой психики: [монография]/ Абрахам Маслоу; [пер. с англ.]. - Санкт-Петербург : Евразия, 1997. - 430 с. 6. Методика навчання мистецтва у початковій школі : [посібник для вчителів] / [под ред. Л. М. Масол]. - Харків : Ранок, 2006. - 256 с. 7. Рудницька О. П. Педагогіка: загальна та мистецька: [навч. посібник] / Оксана Петрівна Рудницька. - Київ : Знання, 2002. 270 с. 8. Сухомлинский В. А. Духовный мир школьника / Василий Александрович Сухомлинский // Избранные произведения: в 5-ти томах. - Київ : Радянська школа, 1979. - Т. 1. - 568 с. 9. Тарасов Г. С. Психология музыкального воспитания школьников / Г. С. Тарасов // Вопросы психологии. - 1991. - № 1. - C. 58-74. 10. Философский энциклопедический словарь / [под ред. И. Т. Фролова]. - Москва : Политиздат, 1987. - 590 с. 11. Шаров Ю. В. О сущности, специфике и классификации духовных потребностей / Юрий Владимирович Шаров // Проблемы формирования социогенных потребностей: материалы I Всесоюзной конференции (Тбилиси, 4-5 ноября 1974 г.). - Тбилиси. - С. 47-49. 12. Шульженко А. Н. Гносеологические основы музыкально-эстетического воспитания: [учебн. пособие для студ. муз.-пед. фак-тов] / Алим Никитович Шульженко. - Москва : Просвещение, 1992. - 236 с.

\section{ПІДГОТОВКА МАЙБУТНІХ УЧИТЕЛІВ ДО ОРГАНІЗАЦІЇ МОРАЛЬНОГО ВИХОВАННЯ УЧНІВ}

Підборський Ю. Г. Підготовка майбутніх учителів до організації морального виховання учнів.

У статті розглнуто питання підготовки майбутніх учителів до організації морального виховання у загальноосвітній школі, а також питання підготовки нової генерації педагогічних кадрів. Розкрито особливості діяльності суб’єктів морального виховання; шляхи максимальної активізації учнів як суб’єктів навчально-виховного процесу; форми і методи виховання, які грунтуються на гуманних стосунках педагогів і учнів.

Ключові слова: учителі, професійна підготовка вчителя, моральне виховання учнів, загальноосвітня школа.

Підборський Ю. Г. Подготовка будущих учителей $\quad$ к организации нравственного воспитания учащихся.

В статье рассматриваются вопросы подготовки будущих учителей к организации нравственного воспитания в общеобразовательной школе, а так же вопросы подготовки новой генерации педагогических кадров. Раскрыты особенности деятельности субъектов 
морального воспитания; пути максимальной активизации учеников как субъектов учебновоспитательного процесса; формы и методы воспитания, которые базируються на гуманных отношениях педагогов и учеников.

Ключевые слова: учителя, профессиональная подготовка учителя, нравственное воспитание учеников, общеобразовательная школа.

Pidborskyi Yu. G. Future teachers training for organization of pupils' moral education.

In the paper the questions of future teachers training for organization of moral education at comprehensive school, as well as questions of training of teaching staff of new generation are examined. Activity features of subjects of a moral education; ways of the maximum activization of pupils as subjects of education process; forms and methods of education which are based on the human relations of teachers and pupils are given.

Key words: teachers, teacher' professional training, moral education of students, secondary school.

В умовах розбудови та становлення національної системи освіти набуває актуальності проблема морального виховання учнів - майбутнього нашої країни. Основа моральності закладається в дитячі роки. У «Розмові з молодим директором школи» В. Сухомлинський як педагог i громадянин зауважує: «...займіться перспективою становлення людинигромадянина», адже «дитина, якій сьогодні сім років, яка несміливо переступає поріг школи і виводить у зошиті кружечки i палички, через десять років, на ваших очах стане громадянином» [5, с. 559]. Моральне осереддя людини залежить «від того, що увійшло в ії серце в роки дитинства і отроцтва, що схвилювало, стривожило їі думку, що наболіло на душі, як каже народ» [6, с. 311].

Результат розв’язання провідного завдання національної освіти України - формування свідомого громадянина, залежить від якості підготовки нової генерації педагогічних кадрів. Саме від особистості вчителя залежить не тільки виховання і навчання дітей, а й розвиток їхніх моральних, національних уподобань і переконань, тому на вищі навчальні заклади покладається особлива відповідальність у підготовці майбутніх учителів до морального виховання учнів.

Широкому колу питань професійної підготовки сучасного вчителя національної школи України присвячені праці А. Алексюка, В. Бондаря, О. Киричука, Н. Кічук, О. Мороза, О. Савченко та ін. Значення моральної підготовки майбутнього вчителя, спрямованої на формування особистості школяра, розкрито у працях І. Беха, І. Звєревої, I. Зязюна, В. Киричок, Т. Люриної, О. Семеног, К. Чорної та ін.

Проблема морального виховання учнів і молоді досліджувалася в різних напрямах, а саме: ознайомлення дітей у дошкільних навчальних закладах з українським народознавством (А. Богуш, Н. Кирста, Н. Лисенко, Н. Луцан, Л. Петлицька та ін.); виховання духовної культури дітей дошкільного і молодшого шкільного віку (І. Бужина, Я. Журецький, Г. Майборода, Н. Чернуха); залучення дітей до української народної творчості (В. Зелюк, Г. Кловак, Е. Павленко та ін.); виховання учнів і молоді на засадах народної педагогіки (І. Зайченко, О. Соколовська, М. Стельмахович, Е. Сявавко); залучення учнів до українських національних звичаїв і традицій (О. Батухніна, С. Ласунова, В. Стрельчук, 3. Файчак).

Аналіз психолого-педагогічних досліджень та стану підготовки майбутніх учителів до морального виховання учнів, а також рівня їхньої моральності, дало змогу виявити основну суперечність у навчально-виховній діяльності загальноосвітньої школи, яка виникла між 
необхідністю забезпечення високого рівня морального виховання і недостатнім рівнем науково-обгрунтованої системи підготовки вчителів до розв’язання цієї педагогічної проблеми. Усунення окресленої суперечності передбачає організацію цілеспрямованої роботи щодо формування у студентів педагогічних університетів готовності до роботи 3 учнями загальноосвітньої школи в аспекті морального виховання, що і зумовило мету нашої статті.

Мета статmі: розкрити сутність, зміст, структуру готовності майбутніх учителів до морального виховання учнів.

Моральне виховання може бути ефективним тільки за вимогливого ставлення педагога до учнів, високого рівня культури відносин у колективі. Вирішальне значення має моральне право вчителя на схвалення чи осуд того, що хвилює вихованців, щоб засудження негативних сторін нашого життя з уст педагога учні сприймали як утвердження правди. Причому сам вихователь повинен мати високий поріг моральності.

У сучасній загальноосвітній школі ідеї морального виховання органічно вписуються у зміст і методику навчальної і позанавчальної роботи, в організацію життєдіяльності школярів. Для учнів цей напрям виховання має на меті формування в дітей знань і уявлень про загальнолюдські цінності, мораль, рідний край, розкриття на доступному рівні особливостей взаємодії людей у родині, в колективі, суспільстві; виховання гуманної, соціально активної, відповідальної особистості.

У сучасних умовах значно ускладнюються функції виховної діяльності вчителів, збагачується ії зміст. За таких умов майбутні вчителі повинні знати, на яких напрямках зосередити свої зусилля, на які виховні ідеали орієнтуватись, як організовувати роботу в дитячому колективі, як на практиці здійснювати демократизацію та гуманізацію виховного процесу в школі.

Як зазначає О. Савченко [4, с. 128], відповідно до вікових і пізнавальних можливостей учнів мета морального виховання реалізується на засадах системного підходу різними шляхами: через взаємодію виховного потенціалу змісту різних предметів (найбільшою мірою це міжпредметні зв’язки із темами курсу «Я і Україна» і предметів «Читання», «Історія України», «Українська література»); демократичні, гуманні методи і форми організації співпраці дітей і дорослих в урочній і позаурочній діяльності; розширення зв’язків дітей 3 соціумом, залучення до участі в дитячих та молодіжних організаціях, в проектах, що сприяє набуттю позитивного індивідуального досвіду взаємодії в колективі; досягнення єдності вимог школи і родини в моральному вихованні дітей.

Реалізація завдань морального виховання в загальноосвітній школі передбачає застосування різних засобів: рідної мови, історії, родоводу, краєзнавства, мистецтва, природи рідного краю, народної міфології, фольклору, народного календаря, національної символіки, родинно-побутової культури тощо.

Вище зазначене дозволяє нам зробити висновок, що важливим аспектом професійної підготовки майбутніх учителів $є$ формування їх готовності до розв'язання завдань морального виховання. Потребують повнішого розкриття особливості діяльності суб'єктів морального виховання; шляхи максимальної активізації учнів як суб’єктів навчальновиховного процесу; форми і методи виховання, які грунтуються на гуманних стосунках педагогів і учнів. Відродження та запровадження національної системи виховання треба розпочинати з формування моральності майбутніх учителів, як риси їх особистості, яка характеризується усвідомленням своїх прав і обов'язків, норм життя; турботою про благополуччя своєї країни, іï̈ громадян, збереження іiї незалежності діями відповідно до 
власних переконань і цінностей. Питання морального виховання з використанням народних традицій вперше в Україні були досить широко висвітлені у підручниках, букварях, календарях для народного читання О. Духновичем, який надавав провідного значення патріотизму, любові та повазі кожного до свого імені та походження, непримиренно ставився до людей, що відмовляються від рідних та близьких, від свого народу. У своїй праці «Народна педагогія на користь училищ та вчителів сільських» він підкреслював: «Щастя або нещастя людини залежить багато разів від народження, але більше від морального ії виховання» [1]. Ця праця опрацьовується студентами та застосовується ними під час проходження педагогічної практики.

Моральність як риса особистості майбутнього вчителя відбиває: моральну самосвідомість, моральну відповідальність, суспільну ініціативність й активність, готовність працювати для розвитку України, захищати ії; ціннісне ставлення до традицій та історії українського народу, усвідомлення своєї належності до нього як його представника, спадкоємця і наступника; гуманність, шанобливе ставлення до культури, традицій, звичаїв національних меншин, високу культуру міжнаціонального спілкування.

Дослідження питань професійної підготовки вчителя доводять, що забезпечення його готовності до професійно-педагогічної діяльності залежить від системи цієї підготовки. Для готовності до дій необхідні знання, уміння, навички, спроможність і рішучість цих дій.

У психолого-педагогічній літературі з проблем підготовки вчителя до професійної діяльності розкриваються різні сторони: структура готовності (О. Мороз), компоненти професійної готовності (Н. Кузьміна, Л. Радченко), професійно-педагогічні чинники (Л. Григоренко).

Чинниками структури готовності до педагогічної діяльності О. Мороз визначає психологічну готовність, теоретичну підготовленість, практичну готовність, необхідний рівень розвитку педагогічних здібностей [3].

Г. Троцко, аналізуючи різні підходи до визначення здатності до педагогічної діяльності, виокремлює такі компоненти: мотиваційно-цільовий; морально-орієнтаційний; операційно-технологічний; творчий потенціал особистості; професійна компетентність; аналітико-оцінний тощо.

Вона підкреслює, що реалізація основних структурних елементів до педагогічної діяльності дозволяє здійснювати відбір змісту та способів підготовки, контролювати та корегувати якість підготовки студентів [7].

Проведений аналіз дозволив нам сформувати сутність «підготовки студентів до морального виховання учнів загальноосвітньої школи»- це системна організація навчальновиховного процесу студентів, що створює умови для виявлення і формування моральності, національної самосвідомості майбутнього вчителя; сприяє виявленню і формуванню творчої індивідуальності особистості майбутнього вчителя; оволодінню ним необхідною системою знань, умінь і навичок для успішної реалізації різноманітних шляхів реалізації цілей морального виховання в загальноосвітній школі.

Готовність студентів до морального виховання - це складне інтегроване поняття, результат теоретичної і практичної підготовки майбутнього вчителя до професійно-виховної діяльності з морального виховання учнів, це концентрований показчик діяльнісної сутності особистості випускника ВНЗ, вимір його професійної і моральної зрілості.

Вивчення реального стану готовності вчителів і студентів до організації та здійснення морального виховання дозволило виявити низку труднощів. 3-поміж них: 
- наявність розриву між теорією і практикою виховання;

- девальвація загальнолюдських, національних цінностей, негативний вплив засобів масової інформації на особистість учня;

- недостатній зв’язок дітей 3 батьками, громадськими дитячими організаціями, позашкільними навчальними закладами;

- недостатній рівень громадянської зрілості студентів та вчителів;

- методична непідготовленість учителів до здійснення морального виховання в загальноосвітній школі.

Результати аналізу практичної підготовки студентів до морального виховання школярів у вищій школі засвідчив низку недоліків в означеній сфері професійної підготовки. Що i зумовило необхідність в нашому досліджені зосередити увагу на визначенні структурних компонентів досліджуваного феномена та визначити організаційно-педагогічні умови підвищення ефективності формування готовності майбутніх учителів до морального виховання учнів загальноосвітньої школи.

Нами визначено структуру готовності майбутніх учителів до морального виховання учнів, яка містить три компоненти: гносеологічний, операційний, ціннісно-мотиваційний.

Перший компонент - гносеологічний - 3 показниками i ознаками їх вияву: обізнаність із сутністю, змістом, засобами, формами і методами морального виховання; знання про сутність моралі, про громадянські, демократичні, загальнолюдські й національні цінності; знання Конституції та інших законодавчих актів про права і обов'язки громадян держави; знання історії, традицій, символів країни; обізнаність із сутністю і специфікою морального виховання.

Другий компонент - операційний - 3 показниками і ознаками їх вияву: вміння формулювати мету і завдання морального виховання учнів з різним рівнем сформованості і вияву моральності; вміння розробляти плани, сценарії і конспекти виховних заходів 3 учнями; вміння здійснювати моральне виховання учнів на практиці; практичні вміння створення сприятливого моральному вихованню укладу шкільного життя; володіння зразками моральної поведінки.

Третій компонент - ціннісно-мотиваційний - 3 показниками i ознаками їх вияву: моральні цінності, громадянські цінності, соціально-політичні цінності, загальнолюдські цінності; ціннісні ставлення до історії, традицій, мови, державної символіки України; бажання, потреба сприяти становленню й утвердженню України як правової, демократичної, соціальної держави; готовність відстояти незалежність Батьківщини; спрямованість на формування моральності учнів.

Діагностування рівня готовності студентів до морального виховання учнів за кожним визначеним компонентом (критерієм) підтвердило, що майбутні фахівці виявляють стійке прагнення до професійного розв’язання завдань морального виховання учнів; усвідомлюють значення морального виховання як суттєвої передумови їхньої плідної педагогічної роботи після закінчення ВНЗ. Водночас дані проведеного анкетування засвідчили, що більшість майбутніх учителів методично недостатньо підготовлені до здійснення означеного виду професійної діяльності.

У процесі теоретичного дослідження підготовки студентів до морального виховання учнів на філологічному факультеті університету особлива увага була спрямована на виявлення вихідних положень, визначальних принципів, які відбивають її зміст, форми і методи на кожному етапі навчання студентів. При цьому ми керувалися загальними 
принципами морального виховання:

- принцип гуманізації навчально-виховної роботи (пропагування і здійснення ідей людяності і добра, гуманні стосунки між викладачами і студентами);

- принцип демократизації (варіативність змісту навчально-виховного процесу, розвиток педагогічних засад співробітництва між викладачами і студентами);

- принцип взаємозв'язку між усіма видами професійно-теоретичної i практичної підготовки;

- принцип оптимізації навчально-виховного процесу (створення сприятливого навчального середовища для стимулювання прагнення студентів до опанування різними способами творчої діяльності, необхідними для набуття вищого рівня розвитку відповідних знань, умінь та навичок);

- принцип індивідуалізації (урахування індивідуальних особливостей кожного студента, стимулювання здібностей);

- принцип поєднання педагогічного керівництва 3 ініціативою і самостійністю майбутніх учителів.

Як засвідчують дослідження науковців ефективність підготовки молодих фахівців залежить від сукупності адекватних принципів, функціональної спрямованості навчання, методів, прийомів, засобів та організаційно-педагогічних умов, за яких буде організоване навчання.

Відтак наступною теоретичною позицією було визначення педагогічних умов, які б сприяли реалізації шляхів і засобів підготовки студентів до морального виховання учнів.

У нашому досліджені під умовами ми розуміємо зовнішні відносно особистості студента штучні обставини організації навчального процесу у ВН3, які постають причиною і стимулом якісних позитивних змін особистісного розвитку, зокрема становлення майбутнього учителя, який буде ефективно здійснювати моральне виховання школярів.

Нами було визначено педагогічні умови формування готовності майбутніх учителів до морального виховання учнів. 3-поміж них:

- актуалізація знань моральної спрямованості як підгрунтя усвідомлення їх вагомості у професійній діяльності вчителя;

- органічна єдність трьох компонентів навчально-виховного процесу професійної підготовки: змістового, що адекватно відображає специфіку морального виховання як керованої педагогічної системи; операційного, що озброює студентів уміннями i практичними навичками щодо морального виховання школярів;

- ціннісно-мотиваційний, що стимулює моральну освіту та самоосвіту; стимулює оволодіння зразками моральної поведінки; стимулює професійне самовдосконалення, формує адекватну оцінно-регулятивну діяльність.

Результативність підготовки студентів до здійснення морального виховання учнів залежить від ступеня усвідомлення майбутніми вчителями значущості означеного аспекту в загальній виховній системі сучасної школи і конкретного вчителя. Урахування зазначеного дозволяє дійти висновку, що лише за постійного активного включення студентів у педагогічну ситуацію, спрямовану на оволодіння ними сутністю, змістом, шляхами здійснення морального виховання, відчуваються позитивні зрушення у професійнопедагогічній свідомості та безпосередній діяльності студентів. Включення студентів в означену ситуацію сприяє розширенню педагогічної обізнаності майбутніх учителів, формує методичну озброєність, позитивно-активне ставлення до необхідності морального виховання 
учнів, стимулює потребу в набутті певної системи вмінь і навичок, прагнення до професійного самовдосконалення.

\section{Література}

1. Духнович А. В. Народная педагогика в пользу училищ и учителей сельских. Ч. 1. / А. В. Духнович. - Львов, 1857. - 92 с. 2. Концепція громадянського виховання особистості в умовах розвитку української державності // Педагогічна газета. - 2000. - № 6. - С. 4-6. 3. Мороз О. Г. Підготовка майбутнього вчителя: зміст та організація : [навч. посібн.] / О. Г. Мороз, В. О. Сластьонін, Н. І. Філіпченко. - Київ, 1997. - 168 с. 4. Савченко О. Я. Виховний потенціал початкової освіти / О. Я. Савченко. - Київ : СПД «Цунзинович Т. І.».2007. - 204 с. 5. Сухомлинський В. О. Вибрані твори: у 5 т. / В. О. Сухомлинський. - Київ : Рідна школа, 1977. - Т. 5. - С. 393-628. 6. Сухомлинський В. О. Вибрані твори: у 5 т. / В. О. Сухомлинський. - Київ : Рідна школа, 1977. - Т. 4. - С. 311. 7. Троцко Г. В. Теоретичні питання формування професійно-педагогічної готовності майбутнього вчителя / Г. В. Троцко. - Харків : «ОВС», 2002. - Ч. 1. - 201 с.

УДК 614.8(078.8)

Лариса Семенець

\section{МЕТОДОЛОГІЧНИЙ АСПЕКТ ФОРМУВАННЯ ПРОФЕСІЙНО-ПЕДАГОГІЧНОЇ ГОТОВНОСТІ ДО НАВЧАННЯ УЧНІВ ОСНОВАМ ЗДОРОВ'Я}

Семенець Л. М. Методологічний аспект формування професійно-педагогічної готовності до навчання учнів основам здоров'я.

У роботі з позицій діяльнісного, системного, комплексного, особистісно зорієнтованого, антропологічного, культурологічного, акмеологічного та компетентнісного підходів проаналізовано особливості формування професійної готовності майбутніх учителів до навчання учнів основам здоров’я.

Ключові слова: науковий підхід, готовність, професійно-педагогічна готовність, основи здоров’я.

Семенец Л. Н. Методологический аспект формирования профессиональнопедагогической готовности к обучению учащихся основам здоровья.

В работе с позиций деятельностного, системного, комплексного, личностно ориентированного, антропологического, культурологического, акмеологического и компетентностного подходов проанализированы особенности формирования профессиональной готовности будущих учителей к обучению учащихся основам здоровья.

Ключевые слова: научный подход, готовность, профессионально-педагогическая готовность, основы здоровья.

Semenets L. M. Methodological aspect of formation of professional and pedagogical readiness for students' training of basics of health.

In the article the features of professional readiness formation of future teachers for students' training of basics of health from the activity, system, comprehensive, person-centered, anthropological, cultural, acmeological and competence based approaches have been analysed.

Key words: scientific approach, readiness, professional and pedagogical readiness, basics of health. 